\title{
Analisis Penjualan Sapi Bakalan Peranakan Ongole (PO) Berbanding dengan Sapi Peranakan Simental (PS) Di Pasar Hewan Panceng Kecamatan Panceng Kabupaten Gresik
}

\section{Sales Analysis Cows Going Peranakan Ongole (PO) Compared With Cattle Simental Peranakan (PS) in the Village Animal Market Surowiti Panceng District of Gresik}

\author{
M. Azhar Bashir ${ }^{1}$, Ir. Wardoyo, MMA ${ }^{2}$, Edy Susanto, S.Pt., MP ${ }^{3}$ \\ ${ }^{1}$ Mahasiswa Fakultas Peternakan \\ ${ }^{2}$ Dosen Pembimbing Utama \\ ${ }^{3}$ Dosen Pembimbing Pendamping \\ Program Studi Peternakan \\ Fakultas Peternakan, Universitas Islam Lamongan (UNISLA)
}

\begin{abstract}
RINGKASAN
Pembibitan sapi potong merupakan sumber utama sapi bakalan bagi usaha penggemukan sapi potong di Indonesia. Biro Pusat Statistik (1997) menunjukan bahwa konsumsi daging sapi perkapita rata-rata meningkat dari $0,31 \mathrm{~kg}$ pada tahun 1990 menjadi 0,62 $\mathrm{kg}$ pada tahun 1996.. Maka dari itu penelitian ini mengangkat permasalahan perbandingan presentase penjualan antara Sapi Peranakan Ongole (PO) berbanding dengan Sapi Peranakan Simental (PS) dan faktor-faktor yang mempengaruhi penjualan Sapi Peranakan Ongole (PO) Berbanding dengan Sapi Peranakan Simental (PS) di Pasar Hewan Desa Surowiti Kecamatan Panceng Kabupaten Gresik. Sejalan dengan masalah tersebut dan hipotesis penelitian maka penelitian ini dilaksanakan dengan menggunakan metode analisis data Uji Validitas, Uji Reliabilitas, Uji t, Analisis Regresi Linier Berganda.Hasil analisis menunjukkan bahwa, uji validitas dan reliabilitas semua variabel dinyatakan valid dan reliabel. Perbandingan penjualan sapi bakalan peranakan ongole dan sapi peranakan simental lebih tinggi sapi simental hal ini di buktikan dengan rekapitulasi hasil pengamatan yang memiliki presentase $30 \%$ dibanding $49,7 \%$ dan hasil uji $t$ Responden sebesar $\mathrm{t}_{\text {hitung(PS) }}<$ $\mathrm{t}_{\text {tabel(PS) }}=19,817<2,05183$ dan $\mathrm{t}_{\text {hitung(PS) }}>\mathrm{t}_{\text {tabel(PS) }}=26,843>2,05183$. Sedangkan Hasil regresi linier berganda menunjukkan $\mathrm{Y}_{(\mathrm{PO})}=1,721+0,349+-0,021+-0,091$ sedangkan $\mathrm{Y}_{(\mathrm{PS})}=3,078+0,074+-$ $0,213+0,007$. Hasil uji $\mathrm{t}$ menyatakan bahwa $\mathrm{t}_{\text {hitung(PO) }}<\mathrm{t}_{\text {tabel }}$ yaitu 2,780 $<2,05183$ dan $\mathrm{t}_{\text {hitung(PS) }}<\mathrm{t}_{\text {tabel }}$ yaitu $0,631<2,05183$, maka dapat disimpulkan bahwa variabel Tangibles $\left(\mathrm{X}_{1}\right)$ berpengaruh terhadap Penjualan (Y). Sedangkan pada variabel keunggulan $\left(\mathrm{X}_{2}\right), \mathrm{t}_{\text {hitung(PO) }}<\mathrm{t}_{\text {tabel }}$ yaitu-0,182 $<2,05183$ dan $\mathrm{t}_{\text {hitung(PS) }}<\mathrm{t}_{\text {tabel }}$ yaitu $-1,712<2,05183$, maka dapat disimpulkan bahwa variabel keunggulan $\left(\mathrm{X}_{2}\right)$ tidak berpengaruh terhadap Penjualan (Y) pada Sapi Bakalan Peranakan Ongole dan Sapi Bakalan Peranakan Simental di Pasar Hewan Desa Surowiti Kecamatan Panceng Kabupaten Gresik. Dan pada variabel Harga $\left(\mathrm{X}_{3}\right)$ Karena $t_{\text {hitung(PO) }}>\quad t_{\text {tabel }}$ yaitu-0,172<2,05183 dan $t_{\text {hitung(PS) }}<t_{\text {tabel }}$ yaitu $-0,094<2,05183$, maka dapat disimpulkan bahwa variabel Harga $\left(\mathrm{X}_{3}\right)$ tidak berpengaruh terhadap Penjualan (Y) pada Sapi Bakalan Peranakan Ongole dan Sapi Bakalan Peranakan Simental di Pasar Hewan Desa Surowiti Kecamatan Panceng Kabupaten Gresik. Berdasarkan temuan-temuan tersebut maka Pasar hewan Desa Surowiti kecamatan Panceng kabupaten Gresik hendaknya berusaha mendapatkan pemahaman yang lebih baik mengenai harapan konsumen (pembeli) melalui riset, analisis komplain, dan lain-lain. Pasar hewan Desa Surowiti kecamatan Panceng kabupaten Gresik perlu mengkaji lebih mendalam dan mampu melakukan riset pemasaran secara berkelanjutan untuk menentukan strategi pemasaran agar dapat memaksimalkanPotensi wilayah kususnya daerah pantura.
\end{abstract}

\section{ABSTRACT}

Beef cattle breeding is the main source of cattle for fattening beef cattle in Indonesia. Central Bureau of Statistics showed that the consumption of beef per capita average increased from $0.31 \mathrm{~kg}$ in 1990 to $0.62 \mathrm{~kg}$ in 1996. In addition, cows imported from Australia is also a source of cows that are important to business fattening, although still relatively small perananya, this shows the bottom of the main source of beef for the National consumption is still dependent on breeding in the State in the form of farm people .. Sapi Peranakan Ongole is a cross between a stud cow cow Sumba Ongole (SO) with cows 
Java is white. This cow has several keungulan that is resistant to heat, resistant to Ekto and endoparasit, relatively rapid growth despite the adaptation to feed less, the percentage of carcass and meat quality is good, and has a good quality cement for the bulls . Cattle Simental Peranakan Ongole (Simpo) is a cross between a cow and a cow Simental Peranakan Ongole, this cow is a cow that many types of race developed in Indonesia which has a productivity oktimal. This research aims to compare the percentage of sales between Ox Peranakan Ongole (PO) compared with the cow Peranakan Simental (PS) and the factors that affect the sales of cow Peranakan Ongole (PO) Compared with Peranakan Cattle Simental (PS) in the Animal Village Surowiti Subdistrict Panceng Gresik. In line with these problems and the research hypothesis, this study was conducted using data analysis methods Test Validity, reliability test, $t$ test, Linear Regression Analysis Berganda.Hasil analysis shows that, the validity and reliability of all the variables declared valid and reliable. ongoing basis to determine marketing strategies in order to memaksimalkanPotensi kususnya region north coast region.

Keyword :Sales Analysis Cows Going Peranakan Ongole (PO) Compared With Cattle Simental Peranakan (PS)

\section{PENDAHULUAN}

Pembibitan sapi potong merupakan sumber utama sapi bakalan bagi usaha penggemukan sapi potong di Indonesia. Selain itu, sapi asal impor dari Australia juga merupakan sumber sapi bakalan yang makin penting bagi usaha penggemukan, walaupun perananya relative masih kecil (Hadiet al., 1999a). Hal ini menunjukan bawah sumber utama daging sapi bagi konsumsi Nasional masih tergantung pada usaha pembibitan di dalam Negeri yang berupa peternakan rakyat. Sampai saat ini masih belum ada perusahaan swasta atau perusahaan Negara yang bergerak di bidang pembibitan sapi potong karena usaha tersebut di nilai kurang menguntungkan (Hadi dan Ilham, 2000).

Biro Pusat Statistik (1997) menunjukan bahwa konsumsi daging sapi perkapita rata-rata meningkat dari $0,31 \mathrm{~kg}$ pada tahun 1990 menjadi $0,62 \mathrm{~kg}$ pada tahun 1996. Selanjutnya Hadi et al. (1999) memproyeksikan bawah total permintaan daging sapi untuk konsumsi langsung dan industry pengolahan makanan secara Nasional akan meningkat dari 197.890 ton pada tahun 2000 menjadi 249.730 ton pada tahun 2003. Untuk memenuhi kebutuhan daging sapi terus meningkat di lakukan impor ternak hidup dan daging .Hadi et al. (1999) memproyeksikan bahwa impor ternak bakalan dan daging sapi masing-masing akan mencapai 446.225 ekor dan 23.520 ton pada tahun 2003.

Sapi Peranakan Ongole merupakan sapi persilangan antara pejantan Sapi Sumba Ongole (SO) dengan Sapi betina Jawa yang berwarna putih. Sapi ini memiliki beberapa keungulanya

itu tahan terhadap panas, tahan terhadap ekto dan endo parasit, pertumbuhan relative cepat meskipun adaptasi terhadap pakan kurang, prosentase karkas dan kualitas daging baik, serta memiliki kualitas semen yang baik bagi sapi jantan (Anonimus, 2012).

Sapi Simental Peranakan Ongole (SimPO) merupakan sapi persilangan antara Simental dan Sapi Peranakan Ongole, sapi ini merupakan jenis bangsa sapi yang banyak di kembangkan di Indonesia yang memiliki produktivitas optimal (Anonimus, 2009).

Jawa Timur merupakan wilayah yang potensial dalam memasarkan hewan ternak, seperti yang di jelaskan Kasubdin Peternakan Gresik, Nunung Dyah Sulistyawati menjelaskan, pasar hewan yang ada di Gresik ada 4 lokasi masing-masing Pasar Hewan Kedungpring, Pasar Hewan Balongpanggang keduanya ada di Kecamatan Balongpanggang, Pasar Hewan Dukun dan Pasar Hewan Surowiti Panceng.Sedangkan, untuk Pasar Hewan Surowiti Panceng seluas $5.800 \mathrm{~m} 2$ yang beraktifitas setiap hari Selasa ini memang tampak paling ramai. Sirkulasi hewan ternak di tempat ini ada sekitar 350 ekor setiap beroperasi. Baik itu hewan sapi maupun kambing.

\section{MATERI PENELITIAN}

Sesuai dengan tujuan yang ingin dicapai dalam penelitian ini, yaitu menjelaskan perbandingan prosentase penjualan dua variabel yang sudah ditetapkan, maka jenis pendekatan yang digunakan adalah Pendekatan Kuantitatif dengan menggunakan jenis penelitian Survay.

Survey adalah metode riset dengan menggunakan kuesioner sebagai instrumen 
pengumpulan datanya. Tujuannya untuk memperoleh informasi tentang sejumlah responden yang dianggap mewakili populasi tertentu. (Sugiyono, $2012: 21$ ).

\section{VARIABEL PENELITIAN}

a. Variabel bebas atau variabel penyebab (independent variables)

Variabel bebas adalah variabel yang menyebabkan atau memengaruhi, yaitu faktor-faktor yang diukur, dimanipulasi atau dipilih oleh peneliti untuk menentukan hubungan antara fenomena yang diobservasi atau diamati.

b. Variabel terikat atau variabel tergantung (dependent variables).

Variabel terikat adalah faktor-faktor yang diobservasi dan diukur untuk menentukan adanya pengaruh variabel bebas, yaitu faktor yang muncul, atau tidak muncul.

\section{Uji Validitas}

\section{METODE ANALISIS DATA}

Menurut Sugiyono (2010 : 269) validitas adalah suatu ukuran yang menunjukkan tingkattingkat kevalidan, atau kesahihan suatu instrumen. Untuk menguji validitas instrumen penelitian digunakan teknik Korelasi Product Moment yang dirumuskan (Sugiyono, 2010 : 269) sebagai berikut:

$$
r_{x y}=\frac{N \cdot \sum X Y-\left(\sum Y\right)}{\sqrt{\left[\left(N \cdot \sum X^{2}-\left(\sum X\right)\left(N \cdot \sum Y^{2}-\left(\sum Y\right)^{2}\right]\right.\right.}}
$$

Dimana :

$$
\begin{aligned}
& \mathrm{R}_{\mathrm{xy}}=\text { Koefisien Product Moment } \\
& \mathrm{X}=\text { Skor Variabel bebas }(\mathrm{X}) \\
& \mathrm{Y}=\text { Skor Variabel terikat }(\mathrm{Y}) \\
& \mathrm{N}=\text { Jumlah Responden }
\end{aligned}
$$

Valid tidaknya suatu item instrumen dapat diketahui dengan membandingkan indeks Korelasi Product Moment dengan level signifikan 5\%. Bila probabilitas hasil korelasi lebih kecil dari 0,05 maka instrumen dinyatakan valid. Sebaliknya, jika hasil korelasi lebih besar dari 0,05 maka instrumen dinyatakan tidak valid. Selain itu juga dapat dilihat dengan menggunakan $\mathrm{a}=0,05(5 \%)$ diketahui $\mathrm{r}_{\text {hitung }}>$ $r_{\text {tabel. }}$. Apabila $r_{\text {hitung }}<r_{\text {tabel }}$ maka status kuesioner adalah gugur (Hadi dalam Sunyoto, 2014 :

\section{Uji Reliabilitas}

Arikunto (2010 : 221) mendefinisikan realiabilitas sebagai suatu instrumen yang cukup dapat dipercaya untuk digunakan sebagai alat pengumpul data karena instrumen tersebut sudah baik. Instrumen yang baik tidak akan bersifat tendensius mengarahkan responden untuk memilih jawaban tertentu. Instrumen yang sudah dapat dipercaya, yang reliabel akan menghasilkan data yang dapat dipercaya pula.

Uji reliabilitas adalah alat untuk mengukur suatu kuesioner yang merupakan indikator dari variabel atau konstruk. Uji reliabilitas merupakan indeks yang menunjukkan sejauh mana alat ukur yang dapat dipercaya atau diandalkan untuk diuji. Kuesioner reliabel atau tidak reliabel dapat menggunakan Alpha Cronbach. Kuesioner reliabel jika Alpha Cronbach> 0,60 dan tidak reliabel jika sama dengan atau di bawah 0,60 (Danang Sunyoto, 2014 : 125).

\section{Analisis Regresi Linier Berganda}

Analisis regresi berganda merupakan teknik analisa yang digunakan oleh seorang peneliti, bila peneliti bermaksud meramalkan bagaimana keadaan (naik turunnya) variabel dependen, bila dua atau lebih variabel independen sebagai faktor prediktor dimanipulasi (dinaik turunkan nilainya). Jadi analisis regresi berganda akan dilakukan bila jumlah variabel independennya minimal 2 . Teknik analisa regresi berganda dapat dihitung dengan menggunakan rumus (Prof. DR. Sugiyono, 2011:275).

$$
Y=a+b_{1} X_{1}+b_{2} X_{2}+b_{3} X_{3}+b_{4} X_{4}+b_{5} X_{5}+e
$$

Dimana :

$\mathrm{Y}=$ Nilai prediksi

$\mathrm{A}=$ bilangan konstan

$\mathrm{b}_{1}, \mathrm{~b}_{2}, \mathrm{~b}_{3}, \mathrm{~b}_{4}, \mathrm{~b}_{5}=$ Bilangan Regresi

$\mathrm{X}_{1}, \mathrm{X}_{2}, \mathrm{X}_{3}, \mathrm{X}_{4}, \mathrm{X}_{5}=$ Variabel Independen

$\mathrm{E}=$ Variabel diluar model

\section{Uji t}

Uji t digunakan untuk mengetahui ada tidaknya hubungan atau pengaruh yang berarti (signifikan) antara variabel independen secara 
parsial terhadap variabel dependen (Danang Sunyoto, 2014 : 118).

Hasil uji t merupakan hasil pengambilan keputusan terhadap hipotesis statistik :

$Y=a+b_{1} X_{1}+b_{2} X_{2}+b_{3} X_{3}+b_{4} X_{4}+b_{5} X_{5}+e$

$\mathrm{H}_{0}=\mathrm{b}_{1}=\mathrm{b}_{2}=\mathrm{b}_{3}=\mathrm{b}_{4}=\mathrm{b}_{5}=0$, artinya tidak ada pengaruh yang signifikan antara variabel independen secara parsial terhadap variabel dependen.

$\mathrm{H}_{0} \neq \mathrm{b}_{1} \neq \mathrm{b}_{2} \neq \mathrm{b}_{3} \neq \mathrm{b}_{4} \neq \mathrm{b}_{5} \neq 0$, artinya ada pengaruh yang signifikan antara variabel independen terhadap variabel dependen.

\section{HASIL DAN PEMBAHASAN}

\subsection{Perbandingan Prosentase Penjualan}

Berdasarkan hasil pengamatan pasar yang terhitung mulai 17 Mei sampai 21 Juni 2016 mengenai penjualan Sapi Bakalan Peranakan Ongole dan Sapi Peranakan Simental di peroleh data sebagai berikut :

Table 2

Rekapitulasi hasil pengamatan pasar (Lampiran 3)

\begin{tabular}{|c|c|c|c|c|c|c|}
\hline \multicolumn{4}{|c|}{ Sapi Peranakan Ongole } & \multicolumn{3}{|c|}{ Sapi Peranakan Simental } \\
\hline $\mathrm{N}$ & $\begin{array}{l}\text { Sapi } \\
\text { Masuk }\end{array}$ & $\begin{array}{l}\text { SapiT } \\
\text { erjual }\end{array}$ & $\%$ & $\begin{array}{l}\text { Sapi } \\
\text { Masuk }\end{array}$ & $\begin{array}{l}\text { Sapi } \\
\text { Terjual }\end{array}$ & $\%$ \\
\hline 1 & 63 & 38 & 23,9 & 72 & 51 & 36,7 \\
\hline 2 & 68 & 41 & 27,9 & 81 & 63 & 51,03 \\
\hline 3 & 64 & 32 & 20,5 & 77 & 49 & 37,73 \\
\hline 4 & 76 & 55 & 41,8 & 87 & 66 & 57,42 \\
\hline 5 & 72 & 52 & 37,4 & 87 & 69 & 60,03 \\
\hline 6 & 71 & 46 & 32,7 & 84 & 66 & 55,44 \\
\hline 7 & $\begin{array}{l}\sum \text { po } \\
\text { masuk } \\
=414\end{array}$ & $\begin{array}{l}\sum \text { po } \\
\text { terjual } \\
=264\end{array}$ & 184,2 & $\begin{array}{l}\sum \text { po } \\
\text { masuk } \\
=488\end{array}$ & $\begin{array}{l}\sum \text { po } \\
\text { terjual } \\
=364\end{array}$ & 298,35 \\
\hline & $\begin{array}{l}\text { Rata- } \\
\text { rata } \\
=69\end{array}$ & $\begin{array}{l}\text { Rata- } \\
\text { rata } \\
=44\end{array}$ & $\begin{array}{l}\text { Rata- } \\
\text { rata } \\
=30,7\end{array}$ & $\begin{array}{l}\text { Rata- } \\
\text { rata } \\
=81,3\end{array}$ & $\begin{array}{l}\text { Rata- } \\
\text { rata } \\
=60,7\end{array}$ & $\begin{array}{l}\text { Rata- } \\
\text { rata } \\
=49,7\end{array}$ \\
\hline
\end{tabular}

Sumber : Data Diolah, hasil pengamatan pasar. Sapi Masuk dan Terjual(2016)

Table 3

\section{Rekapitulasi hasil Uji t pengamatan} pasar (Lampiran 7)

\begin{tabular}{|c|c|c|c|}
\hline & & $\mathrm{T}_{\text {hitung }}$ & $\mathrm{t}_{\text {tabel }}$ \\
\hline Sapi PO & & 12.396 & 2,57058 \\
\hline $\begin{array}{l}\text { Sapi } \\
\text { Simental }\end{array}$ & Peranakan & 17.481 & 2,57058 \\
\hline
\end{tabular}

Sumber : Data Diolah, SPSS Versi 19,0 (2016)

Berdasarkan hasil analisa dari tabel 2 dan 3 dapat disimpulkan bahwa perbandingan penjualan Sapi bakalan Peranakan Ongole dan Sapi Peranakan Simental lebih tinggi Sapi Peranakan Simental hal ini di buktikan dengan rekapitulasi hasil pengamatan yang memiliki persentase $30 \%$ Berbanding 49,7\% dan hasil Uji $\mathrm{t}$ Responden sebesa $\mathrm{rt}_{\text {hitung }(\mathrm{PO})}>\mathrm{t}_{\text {tabel }(\mathrm{PO})}=19,817>$ 2,05183 dan $t_{\text {hitung(PS })}>t_{\text {tabel }(P S)}=26,843>2,05183$.

Menurut Sugeng (1996) Sapi Simental memiliki postur tubuh yang besar, pertumbuhan otot sangat baik, tidak banyak penimbunan lemak di bawah kulit dan berat badan betina mencapi $800 \mathrm{~kg}$ dan jantan $1150 \mathrm{~kg}$.

\subsection{Uji Validitas}

Pada Uji validitas ini dilakukan antara instrumen dengan indikator Sapi Peranakan Ongole dan Sapi Peranakan Simental. Hasil pengujian uji validitas dengan menggunakan data kuisioner di lapangan. Dengan rincian sebagai berikut:

Tabel 4.

Rekapitulasi Hasil Uji Validitas SapiBakalanPeranakanOngole (PO) (Lampiran 4)

\begin{tabular}{lllll}
\hline No Variabel & \multicolumn{2}{l}{$\begin{array}{l}\text { No. Pearson } \\
\text { Item Correlation }\end{array}$} & $\begin{array}{l}\text { Signifikan } \\
\text { (2- tailed) }\end{array}$ & $\begin{array}{c}\text { Keteran } \\
\text { gan }\end{array}$ \\
\hline 1. Tangibles & $\mathrm{X}_{1.1}$ & $0,668^{* *}$ & 0,000 & Valid \\
$\left(\mathrm{X}_{1}\right)$ & $\mathrm{X}_{1.2}$ & 0,413 & 0,000 & Valid \\
2. Keunggulan & $\mathrm{X}_{2.1}$ & $0,596^{* *}$ & 0,000 & Valid \\
$\left(\mathrm{X}_{2}\right)$ & $\mathrm{X}_{2.2}$ & 0,673 & 0,000 & Valid \\
3. Harga $\left(\mathrm{X}_{3}\right)$ & $\mathrm{X}_{3.1}$ & 0,496 & 0,000 & Valid \\
& $\mathrm{X}_{3.2}$ & $0,479^{*}$ & 0,000 & Valid \\
& $\mathrm{X}_{3.3}$ & $0,479^{* *}$ & 0,000 & Valid \\
& $\mathrm{Y}$ & $0,927^{* *}$ & 0,000 & Valid \\
4. Penjualan & & & & \\
$(Y)$ & & & & \\
\hline
\end{tabular}

Sumber : Data Diolah, SPSS Versi 19,0(2016) 
Tabel 5.

Rekapitulasi Hasil Uji Validitas

SapiBakalanPeranakanSimental (Lampiran 4)

\begin{tabular}{llllcl}
\hline $\begin{array}{l}\mathbf{N} \\
\text { o }\end{array}$ & $\begin{array}{l}\text { Variab } \\
\text { el }\end{array}$ & $\begin{array}{l}\text { No. } \\
\text { Item }\end{array}$ & $\begin{array}{l}\text { Pearson } \\
\text { Correlation(2- tailed) }\end{array}$ & $\begin{array}{c}\text { Signifikan } \\
\text { Keter } \\
\text { angan }\end{array}$ \\
\hline 1. & Tangibl & $\mathrm{X}_{1.1}$ & 0,208 & 0,000 & Valid \\
& es $\left(\mathrm{X}_{1}\right)$ & $\mathrm{X}_{1.2}$ & $0,930^{* *}$ & 0,000 & Valid \\
2. & Keunggu $\mathrm{X}_{2.1}$ & $0,844^{* *}$ & 0,000 & Valid \\
& lan $\left(\mathrm{X}_{2}\right)$ & $\mathrm{X}_{2.2}$ & $0,404^{* *}$ & 0,000 & Valid \\
3. & Harga & $\mathrm{X}_{3.1}$ & $0,587^{*}$ & 0,000 & Valid \\
& $\left(\mathrm{X}_{3}\right)$ & $\mathrm{X}_{3.2}$ & $0,760^{* *}$ & 0,000 & Valid \\
& $\mathrm{X}_{3.3}$ & $0,760^{* *}$ & 0,000 & Valid \\
4. & $\begin{array}{l}\text { Penjual } \\
\text { an }(Y)\end{array}$ & $0,805^{* *}$ & 0,000 & Valid \\
\hline
\end{tabular}

Sumber : Data Diolah, SPSS Versi 19,0 (2016)

Berdasarkan hasil analisa dari tabel 4

dan 5 dapat disimpulkan bahwa item variabel

Tangibles $\left(\mathrm{X}_{1(\mathrm{PO})}\right),\left(\mathrm{X}_{1(\mathrm{PS})}\right)$, Keunggulan $\left(\mathrm{X}_{2(\mathrm{PO})}\right)$, $\left(\mathrm{X}_{2(\mathrm{PS})}\right)$, Harga $\left(\mathrm{X}_{3(\mathrm{PO})}\right),\left(\mathrm{X}_{3(\mathrm{PS})}\right)$ dan Penjualan $\left(\mathrm{Y}_{(\mathrm{PO})}\right),\left(\mathrm{Y}_{(\mathrm{PS})}\right)$ dinyatakan valid dengan nilai perbandingan Korelasi Pearson yaitu $\left\{\left(\mathrm{X}_{1.1(\mathrm{PO})}, \mathrm{X}_{1.2(\mathrm{PO})}\right), \quad\left(\mathrm{X}_{\left.2.1(\mathrm{PO}), \mathrm{X}_{2.2(\mathrm{PO})}\right),}\right.\right.$

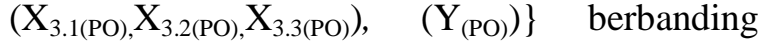
$\left\{\left(\mathrm{X}_{1.1(\mathrm{PS})}, \mathrm{X}_{1.2(\mathrm{PS})}\right),\left(\mathrm{X}_{2.1(\mathrm{PS})}, \mathrm{X}_{2.2(\mathrm{PS})}\right),\left(\mathrm{X}_{3.1(\mathrm{PS})}, \mathrm{X}_{3.2(\mathrm{PS})}\right.\right.$, $\left.\left.\mathrm{X}_{3.3(\mathrm{PS})}\right),\left(\mathrm{Y}_{(\mathrm{PS})}\right)\right\}=\left\{\left(0,668^{* *}, 0,413\right),(0,596\right.$, $\left.0,673),\left(0,496^{*}, 0,749^{* *}, 0,749^{* * *}\right),(0,927)\right\}$ berbanding $\left(0,208,0,930^{* *}\right),\left(0,844^{* *}, 0,404^{* * *}\right)$, $\left.\left(0,587^{* *}, 0,760^{* * *}, 0,760^{* *}\right),\left(0,805^{* *}\right)\right\}$ dan hal ini dibuktikan semua item mempunyai tingkat signifikasi $<0,05$. Sehingga seluruh item yang ada pada item penelitian ini dikatakan layak untuk pengujian selanjutnya.

\subsection{Uji Reliabilitas}

Pada uji reliabilitas ini dilakukan antar variabel seperti terlihat pada tabel 6 dan 7. Hasil pengujian uji reliabilitas dengan menggunakan program SPSS versi 19,0 sebagai berikut :

Tabel 6.

Rekapitulasi Hasil Uji Reliabilitas Sapi Bakalan Peranakan Ongole

\begin{tabular}{|c|c|c|c|c|}
\hline No & Variabel & $\begin{array}{l}\text { Cronbac } \\
\text { h Alpha }\end{array}$ & $\begin{array}{l}\text { Nilai } \\
\text { Kritis }\end{array}$ & $\begin{array}{l}\text { keteranga } \\
\text { n }\end{array}$ \\
\hline 1. & $\begin{array}{l}\text { Tangibles } \\
\left(\mathrm{X}_{1}\right)\end{array}$ & 0,506 & 0,6 & $\begin{array}{l}\text { Tidak } \\
\text { Reliabel }\end{array}$ \\
\hline 2. & $\begin{array}{l}\text { keunggulan }( \\
\left.\mathrm{X}_{2}\right)\end{array}$ & 0,678 & 0,6 & Reliabel \\
\hline 3. & $\operatorname{Harga}\left(\mathrm{X}_{3}\right)$ & 0,772 & 0,6 & Reliabel \\
\hline 4. & Penjualan (Y) & 0,956 & 0,6 & Reliabel \\
\hline
\end{tabular}

Sumber : Data Diolah, SPSS Versi 19,0 (2016)
Tabel 7.

Rekapitulasi Hasil Uji Reliabilitas

\begin{tabular}{lllll}
$\begin{array}{l}\text { Sapi } \\
\text { (Lampiran 5) }\end{array}$ & \multicolumn{1}{c}{ Bakalan } & \multicolumn{2}{c}{ Peranakan } & Simental \\
\hline No & Variabel & $\begin{array}{l}\text { Cronbac } \\
\text { h Alpha }\end{array}$ & $\begin{array}{l}\text { Nilai } \\
\text { Kritis }\end{array}$ & $\begin{array}{l}\text { ketera } \\
\text { ngan }\end{array}$ \\
\hline 1. & $\begin{array}{l}\text { Tangible } \\
\text { s }\left(\mathrm{X}_{1}\right)\end{array}$ & 0,720 & 0,6 & $\begin{array}{l}\text { Reliabe } \\
1\end{array}$ \\
2. & $\begin{array}{l}\text { keunggul } \\
\text { an }\left(\mathrm{X}_{2}\right)\end{array}$ & 0,693 & 0,6 & $\begin{array}{l}\text { Reliabe } \\
1\end{array}$ \\
3. & $\begin{array}{l}\text { Harga } \\
\left(\mathrm{X}_{3}\right)\end{array}$ & 0,771 & 0,6 & $\begin{array}{l}\text { Reliabe } \\
1\end{array}$ \\
4. & $\begin{array}{l}\text { Penjuala } \\
\mathrm{n}(\mathrm{Y})\end{array}$ & 0,891 & 0,6 & $\begin{array}{l}\text { Reliabe } \\
1\end{array}$ \\
\hline
\end{tabular}

Sumber : Data Diolah, SPSS Versi 19,0(2016)

Berdasarkan hasil pengujian pada tabel

6 dan 7 dapat disimpulkan bahwa variabel Tangibles, keunggulan, Harga $\left\{\left(\mathrm{X}_{1(\mathrm{PO})}, \mathrm{X}_{2(\mathrm{PO})}\right.\right.$, $\left.\left.\mathrm{X}_{3}, \mathrm{Y}_{(\mathrm{PO})}\right)\right\}$ Berbanding $\left\{\left(\mathrm{X}_{1(\mathrm{PS})}, \mathrm{X}_{2(\mathrm{PS})}, \mathrm{X}_{3}, \mathrm{Y}_{(\mathrm{PS})}\right)\right\}$ memiliki Cronbach Alpha sebesar $\{0,506$, 0,678, 0,772, 0,956\} Berbanding \{0,720, 0,693, $0,771,0,891\}$ dan dari data perbandingan seluruh item dikatakan reliabel karena memiliki nilai Cronbach Alpha> 0,60,. Sehingga seluruh variabel yang ada pada item penelitian ini dikatakan layak untuk pengujian selanjutnya.

\subsection{Analisis Regresi Linier Berganda}

Pengujian menggunakan regresi linier berganda dilakukan untuk menganalisa pengaruh variabel bebas $(\mathrm{X})$ yaitu Tangibles $\left(\mathrm{X}_{1}\right)$, Keunggulan $\left(\mathrm{X}_{2}\right)$, Harga $\left(\mathrm{X}_{3}\right)$, terhadap variabel terikat yaitu Penjualan(Y) Analisis dilakukan dengan menggunakan program SPSS 19,0 for windows. Sebagaimana hipotesis dalam penelitian ini:

Tingkat kepercayaan yang digunakan dalam perhitungan regresi linier berganda dalam penelitian ini adalah $95 \%$ atau dengan tingkat signifikansi 0,05 (5\%). Secara ringkas hasil analisis regresi linier berganda terdapat pada tabel berikut : 
Tabel 8.

Hasil Analisis Regresi Linier Berganda

\begin{tabular}{|c|c|c|c|c|c|}
\hline Sapi Ba & kalan Pe & lakan & gol & Lampiran & \\
\hline $\begin{array}{c}\text { Varia } \\
\text { bel }\end{array}$ & $\begin{array}{l}\text { Unstanda } \\
\text { rlized } \\
\text { Coefficien }\end{array}$ & $\begin{array}{c}\text { Standardi } \\
\text { zed } \\
\text { Coefficie }\end{array}$ & $t_{\text {hitung }}$ & $\mathbf{t}_{\text {tabel }} \operatorname{Sig} \mathbf{t}$ & $\begin{array}{c}\text { Keput } \\
\text { usan }\end{array}$ \\
\hline & $t$ & $n t(\beta)$ & & & \\
\hline $\begin{array}{c}\text { Constc } \\
\text { nt }\end{array}$ & 1,721 & & & & \\
\hline Tangib & 0,349 & 0,477 & 2,78 & $2,050,01$ & Signifi \\
\hline es $\left(\mathrm{X}_{1}\right.$ & & & 0 & $183 \quad 0$ & kan \\
\hline keung & $-0,021$ & $-0,031$ & - & $2,050,85$ & Signifi \\
\hline ulan & & & 0,18 & 1837 & kan \\
\hline Harga & $-0,091$ & $-0,172$ & - & $2,050,31$ & Signifi \\
\hline$\left(\mathrm{X}_{3}\right)$ & & & 0,17 & $183 \quad 2$ & kan \\
\hline
\end{tabular}

Sumber : Data Diolah, SPSS Versi 19,0(2016)

\section{Tabel 9.}

Hasil Analisis Regresi Linier Berganda

\begin{tabular}{|c|c|c|c|c|c|c|}
\hline \multicolumn{7}{|c|}{ Sapi Bakalan Peranakan Simental } \\
\hline riabel & $\begin{array}{c}\text { Unstanda } \\
\text { rlized } \\
\text { Coefficie } \\
n t\end{array}$ & $\begin{array}{l}\text { Standa } \\
\text { rdized } \\
\text { Coeffi } \\
\text { cient ( } \\
\beta \text { ) }\end{array}$ & $t_{\text {hitung }}$ & $\mathbf{t}_{\text {tabel }}$ & Sig t & $\underset{n}{\text { Keputusa }}$ \\
\hline $\begin{array}{c}\text { Consta } \\
\text { nt }\end{array}$ & 3,078 & & & & & \\
\hline $\begin{array}{l}\text { Tangibl } \\
\text { es }\left(\mathrm{X}_{1}\right)\end{array}$ & 0,074 & 0,120 & 0,631 & $\begin{array}{c}2,0518 \\
3\end{array}$ & $\begin{array}{l}0,53 \\
3\end{array}$ & Signifikan \\
\hline $\begin{array}{c}\text { keungg } \\
\text { ulan } \\
\left(\mathrm{X}_{2}\right)\end{array}$ & $-0,213$ & $-0,336$ & $-1,712$ & $\begin{array}{c}2,0518 \\
3\end{array}$ & $\begin{array}{l}0,09 \\
8\end{array}$ & Signifikan \\
\hline $\begin{array}{c}\text { Harga } \\
\left(\mathrm{X}_{3}\right)\end{array}$ & 0,007 & 0,018 & 0,094 & $\begin{array}{c}2,0518 \\
3\end{array}$ & $\begin{array}{l}0,92 \\
6\end{array}$ & Signifikan \\
\hline
\end{tabular}

Sumber : Data Diolah, SPSS Versi 19,0(2016)

Berdasarkan hasil analisis regresi linier berganda pada tabel 8 dan 9, maka dihasilkan persamaan regresi linier berganda sebagai berikut :

$\mathrm{Y}=\mathrm{a}+\mathrm{b}_{1} \mathrm{X}_{1}+\mathrm{b}_{2} \mathrm{X}_{2}+\mathrm{b}_{3} \mathrm{X}_{3}+\mathrm{e}$

$\mathrm{Y}_{(\mathrm{PO})}=1,721+0,349-0,021-0,091$

$\mathrm{Y}_{(\mathrm{PS})}=3,078+0,074-0,213+0,007$

Dari persamaan regresi linier berganda tersebut diatas, maka dapat diartikan bahwa :

a. $\mathrm{a}_{(\mathrm{PO})}=1,721 \quad \mathrm{a}_{(\mathrm{PS})}=3,078$

Menunjukkan bahwa jika semua variabel bebas tidak mengalami perubahan atau konstan, maka penjualanadalah sebesar $\mathrm{a}_{(\mathrm{PO})}=$ $1,721, \mathrm{a}_{(\mathrm{PS})}=3,078$ b. $b_{1(\mathrm{PO})}=0,349 \quad \mathrm{~b}_{1(\mathrm{PS})}=0,074$

Jika terjadi kenaikan sebesar satu satuan pada variabel Tangibles $\left(\mathrm{X}_{1}\right)$, sedangkan variabel Keunggulan $\left(\mathrm{X}_{2}\right), \quad \operatorname{Harga}\left(\mathrm{X}_{3}\right)$ konstan, maka penjualan naik sebesar $\mathrm{b}_{(\mathrm{PO})}=0,349 / 3,49 \% \mathrm{~b}_{(\mathrm{PS})}$ $=0,074 / 0,74 \%$

c. $b_{2(\mathrm{PO})}=-0,021 b_{2(\mathrm{PS})}=-0,213$

Jika terjadi kenaikan sebesar satu satuan pada variabel keunggulan $\left(\mathrm{X}_{2}\right)$, sedangkan variabel Tangibles $\left(\mathrm{X}_{1}\right), \operatorname{Harga}\left(\mathrm{X}_{3}\right.$ konstan, maka penjualan naik sebesar $b_{2(\mathrm{PO})}=-0,021 /-0,21 \%$, $\mathrm{b}_{2(\mathrm{PS})}=-0,213 /-0,21 \%$

d. $\quad b_{3(\mathrm{PO})}=-0,091 \quad b_{3(\mathrm{PS})}=0,007$

Jika terjadi kenaikan sebesar satu satuan pada variabel Harga $\left(\mathrm{X}_{3}\right)$, sedangkan variabel Tangibles $\left(\mathrm{X}_{1}\right)$, Keunggulan $\left(\mathrm{X}_{2}\right)$, konstan, maka penjualanturun sebesar $b_{3(\mathrm{PO})}=-0,091 /-0,91 \%$, dan penjualan naik $b_{3(\mathrm{PS})}=0,007 / 0,07 \%$. Dari perhitungan regresi linier berganda diatas dapat disimpulkan bahwa seluruh variabel bebas memberikan pengaruh terhadap penjualan sapi di Pasar Hewan Desa Surowiti Kecamatan Panceng Kabupaten Gresik

\subsection{Uji t}

Uji t digunakan untuk menguji secara parsial variabel bebas terhadap variabel terikat. Pengujian ini dilakukan dengan membandingkan nilai $t_{\text {hitung }}$ dengan $t_{\text {tabel }}$. Apabila $t_{\text {hitung }}>t_{\text {tabel }}$ dengan signifikansi 0,05 (5\%), maka secara parsial variabel bebas berpengaruh terhadap variabel terikat. Begitu juga sebaliknya, jika $t_{\text {hitung }}<t_{\text {tabel }}$ dengan signifikansi 0,05 (5\%), maka secara parsial variabel bebas tidak berpengaruh terhadap variabel terikat.Dari hasil pengolahan data dengan menggunakan program SPSS 19,0 For Windows diperoleh hasil uji $\mathrm{t}$ sebagai berikut :

Tabel 10. Hasil Uji t

\begin{tabular}{|c|c|c|c|c|c|}
\hline \multicolumn{6}{|c|}{ Sapi Bakalan Peranakan Ongole (Lampiran 7) } \\
\hline \multirow[b]{2}{*}{ Model } & \multicolumn{2}{|c|}{$\begin{array}{l}\text { Unstandardize } \\
\text { d Coefficients }\end{array}$} & \multirow{2}{*}{$\begin{array}{l}\text { Standardized } \\
\text { Coefficients } \\
\text { Beta }\end{array}$} & \multirow[b]{2}{*}{$\mathrm{T}$} & \multirow[b]{2}{*}{ Sig. } \\
\hline & B & S.E & & & \\
\hline (Constant) & 1.72 & .801 & & 2.149 & .041 \\
\hline Faktor Fisik PO & .349 & .125 & .477 & 2.780 & .010 \\
\hline $\begin{array}{l}\text { Faktor Keunggulan } \\
\text { PO }\end{array}$ & -.02 & .113 & -.031 & -.182 & .857 \\
\hline Faktor Harga & -.09 & .088 & -.172 & -1.03 & .312 \\
\hline
\end{tabular}


Tabel 11.

\section{HasilUji t}

\begin{tabular}{|l|l|l|l|l|l|}
\hline \multicolumn{7}{|c|}{ Sapi Bakalan Peranakan Simental } & \multicolumn{1}{|c|}{} \\
\hline \multirow{7}{*}{$\begin{array}{l}\text { Mnstanda } \\
\text { rdized } \\
\text { Coefficie } \\
\text { nts }\end{array}$} & $\begin{array}{l}\text { Standar } \\
\text { dized } \\
\text { Coeffic } \\
\text { ients }\end{array}$ & T & Sig. \\
\cline { 2 - 6 } $1 \begin{array}{l}\text { B Constant } \\
\text { B }\end{array}$ & $\begin{array}{l}3.07 \\
8\end{array}$ & $\begin{array}{l}\text { SE } \\
\text { Beta }\end{array}$ & & 3.748 & .001 \\
\hline $\begin{array}{l}\text { Faktor } \\
\text { Fisik }\end{array}$ & .074 & .11 & .120 & .631 & .533 \\
\hline $\begin{array}{l}\text { Faktor } \\
\text { Keunggul } \\
\text { an }\end{array}$ & -213 & $\begin{array}{l}.12 \\
4\end{array}$ & -.336 & -1.712 & .098 \\
\hline $\begin{array}{l}\text { Faktor } \\
\text { Harga }\end{array}$ & .007 & .07 & .018 & .094 & .926 \\
\hline
\end{tabular}

a. Dependent Variable: Penjualan

Sumber : Data Diolah, SPSS Versi 19,0 (2016)

a. Uji parsial antara variabel bebas Tangibles $\left(\mathrm{X}_{1}\right)$ dengan Penjualan $(\mathrm{Y})$

dengan $\mathrm{t}_{\text {hitung }(\mathrm{PO})}=2,780 \mathrm{t}_{\text {hitung(}(\mathrm{PS})}=0,631$

Prosedur pengujian uji $\mathrm{t}$ adalah menggunakan uji 2 sisi $(a=5 \%: 2$ $=2,5 \%$ )

a) Dengan $\mathrm{df}=\mathrm{n}-\mathrm{k}-1=31-3-1=27$

b) $t_{\text {tabel }}=t_{0,025(98)}=2,05183$

$$
\text { Karena } t_{\text {hitung(PO) }}>\quad t_{\text {tabel }} \quad \text { yaitu }
$$

$2,780>2,05183$ dan $t_{\text {hitung(PS) }}<t_{\text {tabel }}$ yaitu $0,631<2,05183$ maka dapat disimpulkan bahwa variabel Tangibles $\left(\mathrm{X}_{1}\right)$ berpengaruh terhadap Penjualan (Y) hanya pada jenis Sapi Bakalan Peranakan Ongole dan tidak pada jenis Sapi Bakalan Peranakan Simental di Pasar Hewan Desa Surowiti Kecamatan Panceng Kabupaten Gersik.

Sapi Peranakan Ongole menujukan keunggulan sapi tropis yaitu adaptasi iklim tropis yang sangat tinggi, tahan terhadap panas, tahan terhadap parasit seperti gigitann yamuk dan caplak disamping itu juga menunjukan toleransi yang baik terhadap pakan yang mengandung serat kasar yang tinggi (Astuti : 2005 )

a. Uji Parsial antara variabel bebas keunggulan $\left(\mathrm{X}_{2}\right)$ dengan Penjualan $(\mathrm{Y})$, dengan $\mathrm{t}_{\mathrm{hitung}(\mathrm{PO})}=-$ $0,182 \mathrm{t}_{\text {hitung(PS) }}=-1,712$

a) Dengan $\mathrm{df}=\mathrm{n}-\mathrm{k}-1=31-3-1=27$ b) $\mathrm{t}_{\text {tabel }}=\mathrm{t}_{0,025(98)}=2,05183$

Karena $\quad \mathrm{t}_{\text {hitung(PO) }}<\quad \mathrm{t}_{\text {tabel }} \quad$ yaitu$0,182<2,05183$ dant $_{\text {hitung(PS })}<\quad t_{\text {tabel }}$ yaitu $1,712<2,05183$ maka dapat disimpulkan bahwa variabel keunggulan $\left(\mathrm{X}_{2}\right)$ tidakberpengaruh terhadap Penjualan (Y) pada Sapi Bakalan Peranakan Ongole dan Sapi Bakalan Peranakan Simental di Pasar Hewan Desa Surowiti Kecamatan Panceng Kabupaten Gresik.

a. Uji Parsial antara variabel bebas $\operatorname{harga}\left(\mathrm{X}_{3}\right)$ dengan loyalitas anggota (Y), dengan $\mathrm{t}_{\text {hitung(}(\mathrm{PO})}=-0,172 \mathrm{t}_{\text {hitung }(\mathrm{PS})}=-0,094$

a) Dengan $\mathrm{df}=\mathrm{n}-\mathrm{k}-1=31-3-1=27$

b) $t_{\text {tabel }}=t_{0,025(98)}=2,05183$

Karena $\quad \mathrm{t}_{\text {hitung(}(\mathrm{PO})}<\mathrm{t}_{\text {tabel }} \quad$ yaitu$0,172<2,05183$ dan $\mathrm{t}_{\text {hitung(PS })}<\mathrm{t}_{\text {tabel }}$ yaitu $0,094<2,05183$ maka dapat disimpulkan bahwa variabel Harga $\left(\mathrm{X}_{3}\right)$ tidak berpengaruh terhadap Penjualan (Y) pada Sapi Bakalan Peranakan Ongole dan Sapi Bakalan Peranakan Simental di Pasar Hewan Desa Surowiti Kecamatan Panceng Kabupaten Gresik.

\section{Kesimpulan}

\section{KESIMPULAN DAN SARAN}

Dari pengelolaan data dapat di simpulkan bawah

- Prosentase Penjualan Sapi Bakalan Peranakan Ongole (PO) lebih kecil dari pada Sapi Peranakan Simental (PS) dengan prosentase $30 \%$ dibanding $49,7 \%$ dan hasil uji $\mathrm{t}$ Responden sebesar $\mathrm{t}_{\text {hitung(}(\mathrm{PO})}>\mathrm{t}_{\text {tabel }(\mathrm{PO})}=$ $19,817>2,05183$ dan $t_{\text {hitung(PS) }}>t_{\text {tabel(PS) }}=$ 26,843>2,05183

- Penjualan Sapi Bakalan Peranakan Ongole (PO) dan Sapi Peranakan Simental (PS) di pengarui oleh faktor yaitu Tangibel (fisik), Keunggulan dan harga dengan hasil regresi Linier Berganda yaitu $\mathrm{Y}_{(\mathrm{PO})}=1,721+0,349$ $0,021-0,091$ Berbanding $\mathrm{Y}_{(\mathrm{PS})}=3,078+$ $0,074-0,213+0,007$. Perbedaan terdapat pada factor Tangibles (keunggulan).

2. Saran

- Berusaha mendapatkan pemahaman yang lebih baik mengenai harapan konsumen (pembeli) melalui riset, analisis komplain, dan lain-lain. 
- Pasar hewan Desa Surowiti Kecamatan Panceng Kabupaten Gresikperlu mengkaji lebih mendalam dan mampu melakukan riset pemasaran secara berkelanjutan untuk menentukan strategi pemasaran agar dapat memaksimalkanPotensiwilayahkususnyadaer ahpantura

- Mengantisipasi perubahan keinginan dan kebutuhan konsumen pada berhubungan denganjenissapi, yang dapat berubah sewaktu-waktu.

Memberikan pelayanan yang terbaik agar konsumen terkesan. Karena pelayanan terbaik adalah keberhasilan usaha dari sebuah produk yang dipasarkan.

\section{DAFTAR PUSTAKA}

Arikunto Suharsimi, 2010. Prosedur Penelitian : Suatu Pendekatan Praktek.Jakarta: Rineka Cipta.

Biro Pusat Statistik. 1997. Survai Sosial Ekonomi Nasional (SUSENAS 1996). Biro Pusat Statistik. Jakarta . $232 \mathrm{hlm}$

Bringham, Eugene F. dan Joel F. Houstan. 1986. Manajemen Keuangan. Edisi Ketujuh. Cetakan keempat. Judul Asli; Managerial Finance, $7^{\text {th }}$ Edition. Ahli Bahasa oleh Djoerban Wahid dan Ruchyat Kurasis. Jakarta: Erlangga.

Bloom, Paul N \&Loueis, N.2006. Boone Strategi Pemasaran Produk, 18 Langkah Membangun Jaringan Pemasaran Produk yang Kokoh Ed-1 (Jakarta PrestasiPustaka Raya).

Chandra, Gregorius, Fandy Tjiptono \& Chandra Yanto.2004. Pemasaran Global :Internasionalisasi dan Internetisasi (Yogyakarta : Andi, ).

Danang Sunyoto,2012.Praktik Riset Perilaku Konsumen (Teori, Kuesioner, Alat dan Analisis Data).Yogyakarta : CAPS (Center of Academic Publishing Service).

Dajan Anto. 2008. Pengantar metode staistik. Jilid 1. Jakarta: LP3ES

Frandson, R.D. 1996. Anatomi dan Fisiologi ternak. Edisi ke empat,Gadjah Mada University Press, Yogyakarta.

Hadi, P.U ., D. Vincent, and N. Ilham. 1999a. The impact of the economic crisis on Indonesia's beef sector In Simatupang,
P., S. Pasaribu, S. Bahari, and $R$. Stiringer (Eds). Indonesia's Economic Crisis : Effects on Agricultural and Policy Responses. Published for CASER by Centre for Internasional Economic Studies, University of Adelaide, Australia .p. 303-331

Hadi , P.U dan N. Ilham. 2000. Peluang pengembangan usaha pembibitan ternak sapi potong di Indonesia dalam rangka swasembada daging 2005. Makalah di presentasikan dalam Pertemuan Teknis Penyediaan Bibit Nasional dan Revitalitas UPT T.A 2000. Direktorat Perbibitan, Direktorat Jendral Bina Produksi Peternakan, Jakarta, 11-12 Juli 2000. 22 hal

Hunter, R.H.F., 1995, Fisiologi dan Teknologi Reproduksi Hewan Betina Domestik, Penerbit ITB, Bandung

Jefkins, Frank, 2002, Public Relation, Terjemahan: Haris Munandar, Erlangga, Jakarta.

Kotler.2005. Manajemen Pemasaran

Jilid 2, Terjemahan Benyamin Molan I ndeks, Jakarta

Munawir, S. 2002. Analisis Laporan Keuangan. Edisi keempat. Cetakan Ketigabelas. Yogyakarta: Liberty.

Mulyadi. 1994. Akuntansi Untuk Manajemen. Bagian Penerbit STIE YKPN Yogyakarta.

Rahardi, F \& Hartono, Rudi. 2005.Agribisnis Peternakan (Jakarta : PT. Gramedia Pustaka Utama)

Rangkuti, Fredi, 2009, Marketing Analysis Made Easy, Jakarta, PT Gramedia Pustaka Utama.

Riyadi, Matur. Tantangan dan Peluang Peningkatan Sapi Potong Menuju 2020. (2006). www.bisnis.com. Selasa, 13 September 2006. 17:18

Riyanto, Bambang. 2001. Dasar-Dasar Pembelanjaan Perusahaan. Edisi keempat. Cetakan Ketujuh. Yogyakarta: BPFE.

Sosilorini, 2009. Budidaya dua puluh dua ternak potensial Cetakan Ke III Penerbit Penebar Swadaya Jakarta

Stoner, James AF, et-al 1.996.Manajemen Edisi 1 Bahasa Indonesia. (Jakarta :PT.Prenhalindo) 
Sugiyono, 2010.Metode Penelitian Kuantitatif Kualitatif dan $R$ \& D. Cetakan Ke-11. Bandung : Alfabeta.

Sugiyono,2011.Metode Penelitian Kuantitatif Kualitatif dan $R \quad \& \quad D$. Bandung : Alfabeta.

Sugiyono,2012.Memahami Penelitian Kualitatif. Bandung : Alfabeta.

Sugeng, Y, Bambang.1993.SapiPotong Ed-2 (Jakarta :Penebar Swadaya)

Sunny, T.H. Goh \& Hor-Khengkhoo.2003.Marketing Wise Ed.1 (Jakarta : PT. Buana Ilmu Populer)

Tjipton, Fandy. 2002, Pemasaran Strategi, Edisi Kedua, Cetakan Keenam, Andi, Yogyakrta. 